\title{
Development and Practice of "Work - style" Vocational English Curriculum in Higher Vocational Education
}

\author{
Weiwei Zou \\ Nanchang Institute of Science of Technology, Nanchang, 330108
}

\begin{abstract}
According to the domestic and foreign vocational English curriculum development status, the field of expertise, workplace, work process, typical work tasks, work essentials, development and practice of "Work-style" curriculum of vocational English in Higher Vocational Education based on "6P"Mode of practical training, which reflects the practicality, occupation, task, openness and authenticity of the characteristics in the teaching.

Keywords: Higher Vocational English; "Work-Style"Vocational English Curriculum; "6p"Mode
\end{abstract}

\section{Introduction}

Nowadays, higher vocational education is in reform and development of the critical period, according to the requirement of Ministry of Education "on the promotion of higher vocational education reform and innovation to lead the development of vocational education in a number of opinions", it must be "on the basis of the demand for talent to regional industrial development, clear personnel training objectives, deepen the combination of work, school-enterprise cooperation, internship talent training model reform", curriculum development and construction. Vocational English course in higher vocational colleges must deepen the reform of curriculum according to such requirements, developed a new vocational English curriculum system with the core of practice, based on job requirements, aiming at improve vocational English ability, guided by the process 
of working English, and taking the real task of foreign enterprises as the carrier.How to implement the task-driven and project-oriented teaching mode of the workplace English curriculum, which becomes the main problem to be solved in curriculum development and construction.

\section{The Development of Vocational English Courses at Home and Abroad}

Internationally, VESL (Vocational English as a Second Language), is a model of the vocational English curriculum, which is offered by English-speaking vocational schools and vocational training institutions to solve the problem of language employment from non-English speaking countries and to use English as a second language.

VESL is based on job requirements, vocational skills as the core, its teaching philosophy, teaching objectives, course content, teaching methods, assessment methods are non-native English speakers in the workplace in English to complete the specific work services, so that students can work in English in accordance with the work process to complete the task in order to achieve the completion of procedural work in the operation, to "work in English can do things," the standard, at the same time with required English language skills of the workplace and employers, colleagues and customer exchanges .These are some references for the development of vocational English courses in higher vocational colleges in China, which is the development direction and the goal of vocational English courses in higher vocational colleges.

As a result of the influence of traditional English teaching content and the teaching method, our country's occupation English curriculum still stays in the curriculum pattern, which based on the language system, listening, reading, writing as the main training goal, ignoring the professional ability of the training. Therefore, the vocational education as the basic characteristics of vocational courses should be in-depth development and construction. Of course, due to there are many differences among cultural background, language environment, faculty, teaching conditions, management system, completely copy the VESL model is not realistic in China, which requires vocational higher vocational English courses in the international advanced experience in the absorption, focus on localization development, development and design for their own development of the new vocational English courses. Therefore, it is necessary to reform and innovate the curriculum model from the aspects of teaching idea, teaching goal, course content, teaching method and way of assessment, so as to develop a new curriculum model adapting to the development of higher vocational education. 


\section{The Development of the "Work - style" Curriculum in Vocational}

Vocational English "work style" curriculum is in the domestic and international vocational education on the basis of advanced experience, which conforms to the basic law of the language acquisition process, adapts to the professional ability development, uses the bilingual to carry on the expert instruction, "Work-style" learning, research-style work, competition-based assessment of the curriculum system.

After curriculum development team practices and researches in the enterprise, focus on the practice and research results analysis, and understands the job requirements, determines the teaching objectives. Through the analysis of the (Profession)of the work (Position) of the work process (Procedure), to determine the typical work tasks (Practice), refining the essentials (Point), design a bilingual teaching of the practice of exercise (Performance) teaching project. On the basis of such " $6 \mathrm{P}$ " model, we should develop the teaching material of "work-style" in vocational English, build the "work-style" training venues, establish the simulation working environment, integrate the teaching resource library, establish bilingual teaching methods, system.

For example, in the development process of the "Foreign Trade English" work-style curriculum, the teaching management department joins the related departments and foreign trade enterprises, hires the language experts, the foreign trade enterprise experts and the first-line higher vocational teachers to form the curriculum development team. The course development team is in-depth discussions with large state-owned foreign trade group companies, foreign-funded enterprises, private small foreign trade companies, logistics and transportation companies and other enterprises, and business management, import and export clerk.At the same time, in the case of corporate license, the team members take participate in certain work processes to obtain first-hand information on foreign trade enterprises.

Curriculum development team uphold the students as the main body, alternating engineering, task-driven, project-oriented teaching integration teaching philosophy to develop foreign trade workplace courses.Basis on the foreign trade sector (Profession) of the import and export sales post position (Position) demand, determine the "students can be familiar with the foreign trade environment, understand the job requirements, the use of international business communication skills, independent completion of foreign trade business professional operation"for the teaching objectives.

According to the foreign trade (Procedure), determine customer development, import business, export business and other typical tasks (Practice),measure the difficulty of the task by the front line teachers and language experts on the basis of the characteristics of vocational students.Extract the practical, standard, easy to moderate language point (Point),design a comprehensive combat exercise (Performance) teaching project,compile "foreign trade English" work-style curriculum materials,construct simulation of training room simulation work environment,carry out bilingual task-based teaching, increase students' language 
environment experience and true professional experience.At the same time, regularly employ foreign trade business experts and language experts for job training and language training, and regularly organize students to foreign trade enterprises in batches.Finally, the evaluation of language proficiency, vocational skills and professional accomplishment is assessed by the combination of language evaluation and enterprise assessment.

\section{The Practice of "Work - style" Curriculum in Vocational English}

Vocational English "work - style"curriculum is practical, professional, task, openness and authenticity.Practicality is reflected in the "4O"as a workplace English "work-style"approach.In the "work-style" classroom, teachers guide students in accordance with the teaching objectives (Objectives), organizational arrangements (Organization), require students to follow the professional norms (Obligation) to complete the task training content, and accept teachers comprehensive assessment (Observation). Taking the teaching practice of "foreign trade English" work style "course" as an example,around the typical task design teaching project, each teaching project in accordance with the work process is divided into a number of specific tasks.Each specific task is composed of the work background, work tasks, work control.The organization process, first of all students under the guidance of bilingual teachers to understand the teaching objectives, grouping, learning professional norms.Then, with the help of the teacher, each student chooses a role in the import and export procedure of the foreign trade industry, such as the exporter, the importer, the related bank, the shipping company, the insurance company staff, task.Then, under the bilingual instruction of the teacher, the students read the working background (work environment and task background) in the information table provided in the textbook and the work tasks in the task table (work guide and operation guide).After preparing for the mission, conduct the first bilingual practice exercise and get advice from teachers and other groups.Read the work control (reference material), and then the second show.Finally, under the guidance of teachers, self-assessment, mutual assessment, after comprehensive evaluation of the results of selected groups, submitted to the business experts, access to professional advice. This kind of "work style" course organization practice process is simple, practical and effective.

Occupational reflected in each teaching project are closely around the job responsibility. Foreign Trade English work-style course tasks are based on real business information teaching arrangement, in line with the actual operation of the business process. At the same time, hire business experts and language experts to provide career planning, cross-cultural aspects of the lecture, so as to improve students' cultural adaptability. 
Task reflected in each teaching project is to create a real work situation by the work, the organization of students to complete the typical tasks, develop students' professional English ability.

Openness reflected in the "work-style"course evaluation system is open to the students to provide more play space.Foreign Trade English work-style courses, for example, the group under the guidance of teachers in the self-assessment, mutual assessment, the relationship between the group is a competitive relationship, but also cooperative relations, assessment, good performance team also available Professional advice of business experts.

Authenticity reflected in all the tasks are foreign companies and other foreign companies the real work content."Foreign Trade English work-style course"in all the working materials are processed through the teaching of the actual import and export cases.Use of bilingual communication when working on a task, working with Chinese companies and departments in Chinese, When dealing with foreign enterprises and departments in English, in line with the actual work requirements.

\section{Conclusion}

The class practice of the "work - style" curriculum of vocational English inspires students' interest in learning.Through repeated exercises in the "work-style"scene, students can get basic English language communication skills, but also complete the job, the real experience of the English language communication function, learn to the right occasion to choose the appropriate organization language way of expression.At the same time, students are familiar with the work process, access to vocational skills and related professional experience, become "understand business, can operate, will communicate"higher applied English talents, shorten the occupation adaptation period, foundation.In short, according to the "6P"model to develop vocational English "work-style"course, not only for language communication and skills training, but also to complete the relevant vocational training, vocational English course development trend, in line with the development of vocational education requirements, to better meet the needs of the talent market.

\section{Acknowledgment}

This research was financially supported by the Jiangxi Province Education Reform Foundation.

Project Name:Practice and Application of VESL Teaching Mode in Applied Technological Undergraduate College

Project Number: JXJG-15-27-5

\section{References}

[1] Xiao-dong JIANG , Enlightenment of ESL Curriculum Objectives and 
Teaching Modes on English Teaching in Vocational Schools, [J], Vocational Education Research, 2007, 6.

[2] Xin-yi ZHOU , Development and Practice of "Work - style" Vocational English Curriculum in Higher Vocational Education, [J], Vocational Education Research, 2012.

[3] Xiao-dong JIANG,Ping SHENG, On the Conceptual Model of English Curriculum Reform in Higher Vocational Colleges, [J], Dajia, 2007, 8.

[4] Xiao-dong JIANG , A Probe into English Teaching Objectives from the Perspective of Modern Vocational Education Values, [J], Social Sciences Review, 2012, 7.

[5] Jie LIU,An Investigation on the Market Demand of Vocational English Education in Higher Vocational, [J], Science and Technology Information, 2008,27

[6] Yang-zheng HU,Hotel English service training,[M], Beijing: Tsinghua University Press, 2008 